\title{
PENENTUAN TARIF ANGKUTAN BARANG MODA KERETA API JALUR PADANG-SOLOK
}

\author{
Hardi Wijaya ${ }^{1}$, Purnawan ${ }^{2}$, Hendra Gunawan ${ }^{3}$
}

\begin{abstract}
ABSTRAK
Pemerintah terus mendorong percepatan pembangunan diseluruh wilayah Indonesia. Tidak terkecuali pembangunan infrastruktur di provinsi Sumatera Barat. Salah satu upaya pemerintah mendanai pembangunan infrastruktur adalah bermitra dengan pihak swasta dalam bentuk Kerjasama Pemerintah Swasta (KPS). Unsur terpenting KPS adalah kelayakan ekonomi dan keuangan berupa pengembalian modal. Rencana pembangunan jalur kereta api Padang-Solok tahun 2000 masuk dalam usulan rute pada skema jaringan jalur kereta api Pulau Sumatera. Penentuan tarif merupakan unsur terpenting pengembalian modal investasi. Penelitian ini bertujuan untuk menentukan besaran tarif beberapa jenis komoditi angkutan barang kereta api jalur Padang-Solok. Metode dilakukan dengan tiga cara yaitu survey, tarif berdasarkan tata cara perhitungan yang dilakukan PT Kereta Api Divisi Regional II Sumatera Barat serta perhitungan berdasarkan Peraturan Menteri Perhubungan No. PM 34 Tahun 2011. Dari hasil survei diperoleh Nilai ATP (Abillity to Pay) ratarata pengguna jasa angkutan batu bara sebesar Rp 530,85, semen sebesar Rp 1.005,44, CPO sebesar Rp 519.78, karet sebesar Rp 552.47, beras sebesar Rp 1.027,73, pupuk sebesar Rp 445,45, inti sawit sebesar Rp 500.00 , dan kelontong sebesar Rp 670.53,- /ton / km. Nilai WTP (Willingness to Pay) rata-rata pengguna jasa angkutan batu bara sebesar Rp 499.97, semen sebesar Rp 823.91, CPO sebesar Rp 430.00, karet sebesar Rp 471.94, beras sebesar Rp 855.06, pupuk sebesar Rp 550.00, inti sawit sebesar Rp 166.67, serta kelontong sebesar $\mathrm{Rp}$ 633.83,- /ton / $\mathrm{km}$. Untuk komoditi pupuk nilai ATP lebih kecil dari WTP sedangkan untuk komoditi lainnya nilai ATP lebih besar dari WTP.
\end{abstract}

Kata kunci : Infrastruktur, Kerjasama Pemerintah Swasta, Tarif, Abillity to Pay dan Willingness to Pay

\section{PENDAHULUAN}

Permasalahan utama yang dihadapi dalam meningkatkan pembangunan bidang infrastruktur di Indonesia adalah kebutuhan investasi infrastruktur yang besar, dengan keterbatasan kemampuan APBN. Untuk mencapai target pertumbuhan 7\% dalam RPJM 2010-2014, total kebutuhan dana untuk penyediaan infrastruktur sekitar Rp 1.923,7 trilliun. Kemampuan pemerintah hanya sekitar Rp 559,54 trilliun ditambah dengan potensi pendanaan lain dari BUMN, swasta, dan APBD sekitar Rp 1.040,59 trilliun. Terdapat gap pendanaan sekitar Rp 323,67 trilliun (Natsir, 2011).

Sesuai dengan Master Plan Jalur KA Pulau Sumatera, pembangunan short cut Padang - Solok merupakan bagian dari usulan jaringan jalur KA Sumatera dengan panjang jalur $55 \mathrm{~km}$ dengan biaya US \$ 370 juta. Pembangunan short-cut Padang-Solok telah masuk dalam Dokumen RPJP, RPJM, serta RTRW Provinsi Sumatera Barat (Prayitno, 2011). Dari data Dinas Perhubungan Sumatera Barat dinyatakan bahwa jenis angkutan yang melewati jalur Padang - Solok didominasi

\footnotetext{
${ }^{1}$ Mahasiswa Pascasarjana T. Sipil, hardiw10@gmail.com

${ }^{2}$ Dosen Pascasarjana T. Sipil, purnawan@ ft.unand.ac.id

${ }^{3}$ Dosen Pascasarjana T. Sipil, hendra@ft.unand.ac.id
} 
oleh jenis angkutan barang, yaitu sebesar 70\%. Setiap tahun jumlah angkutan barang ini cenderung meningkat. Dalam kurun waktu lima tahun terakhir (2005-2010) terjadi peningkatan sebesar 1,83\% per tahunnya.

Seffrus (2012) melakukan penelitian yang berjudul estimasi angkutan barang shortcut PadangSolok dari peralihan moda truk ke kereta api sebagai pertimbangan pembangunan proyek kerjasama pemerintah-swasta. Dari penelitian ini, dengan laju pertumbuhan normal didapatkan ramalan jumlah angkutan barang yang melewati jalur Padang-Solok untuk 30 tahun ke depan sebesar 13,124 ton/hari. Hal ini mengarahkan pada pertimbangan pelaksanaan pembangunan dengan skema kerjasama pemerintah - swasta. Pada tahun 2011, arus kendaraan yang melalui jalur Padang - Solok bertambah padat sehingga kemacetan bertambah parah. Ditambah lagi, kondisi jalan Padang - Solok pada beberapa ruas jalan juga mengalami kerusakan sehingga waktu tempuh dari Padang-Solok cukup lama dari biasanya. Kerusakan jalan tersebut sebagian besar disebabkan oleh semakin banyaknya truk angkutan barang melewati jalan Padang - Solok dengan muatan melebihi batas yang dipersyaratkan.

Pembangunan shortcut Padang-Solok dengan skema KPS perlu penyiapan kelayakan proyek berupa prastudi kelayakan proyek kerjasama berupa kajian hukum, teknis, kelayakan ekonomi dan keuangan, sosial dan lingkungan, dukungan dan jaminan pemerintah serta kajian bentuk kerjasama. Dalam kajian kelayakan (ekonomi dan keuangan), unsur terpenting KPS yang perlu dikaji adalah pengembalian investasi. Penelitian ini bertujuan untuk menentukan berbagai jenis tarif angkutan barang kereta api jalur Padang-Solok. Hasil penelitian ini diharapkan dapat dijadikan bahan pertimbangan bagi Pemerintah Daerah Provinsi Sumatera Barat untuk mengkaji lebih lanjut Pembangunan Shortcut Padang-Solok dengan skema kerjasama dengan swasta.

\section{DASAR TEORI}

Tarif didefinisikan sebagai harga atau nilai kompensasi yang harus dibayar konsumen/pengguna atas pengkonsumsian suatu produk jasa, baik melalui mekanisme sewa menyewa, tawar menawar maupun ketetapan pemerintah (Warpani, 2002).

Tarif bagi penyedia jasa transportasi (operator) adalah harga dari jasa yang diberikan. Sedangkan bagi pengguna, besarnya tarif merupakan biaya yang harus dibayarkan untuk jasa yang telah dipakainya. Penentuan tarif ini harus berdasarkan sistim pembentukannya yang diatur oleh pemerintah.Peraturan menteri no. 34 tahun 2011 pasal 11 berbunyi " Tarif angkutan barang dan bagasi dengan kereta api digolongkan atas tarif angkutan barang dan bagasi berjadwal dan tidak berjadwal". Pasal 12 (1) " Tarif angkutan barang dan bagasi berjadwal ditetapkan oleh penyelenggara sarana perkeretaapian". Pasal 13 berbunyi “ Tarif angkutan barang dan bagasi tidak berjadwal ditetapkan berdasarkan kesepakatan penyeleggara sarana perkeretaapian dengan pengguna jasa". Komponen perhitungan biaya penentuan tarif barang dapat dilihat pada Tabel.1

\subsection{Pendekatan Kesanggupan Membayar (Willingness To Pay)}

Pendekatan ini didasarkan pada analogi dari sistem atau mekanisme pasar, dimana terjadinya suatu transaksi di pasar disebabkan oleh terjadinya keseimbangan permintaan dan penawaran, yang tercermin pada harga dan kuantitas produk yang ditransaksikan. Dalam konteks ini, tarif angkutan barang dengan kereta api merupakan harga dari produk jasa pelayanan sarana dan prasarana perkeretaapian atau harga dari suatu produk jasa yang dijual oleh produsen. Agar terjadi suatu kesepakatan transaksi yang saling menguntungkan, khususnya dalam kuantitas yang disepakati, maka harga yang disepakati harus menguntungkan bagi kedua belah pihak. Bagi produsen, kuantitas tersebut haruslah sedemikian rupa sehingga menyebabkan tingkat produksinya relatif ekonomis atau berproduksi pada skala usaha yang ekonomis. Sedangkan bagi konsumen, kuantitas 
produk yang dibeli haruslah berada pada tingkatan yang sesuai dengan daya beli dan nilai utilitas dari pengkonsumsian produk tersebut. Dengan kata lain, harga dari produk jasa sarana dan prasarana perkeretaapian haruslah sesuai daya beli pengguna dan juga memberi keuntungan bagi penyelenggaranya. Karena jika harga terlalu tinggi, maka pengguna akan berkurang, sedangkan jika harga terlalu rendah, maka pengguna akan banyak. Oleh karena itu, dalam pendekatan ini tarif angkutan barang kereta api haruslah relatif sesuai dengan kesanggupan membayar (WTP, willingness to pay) dan kemampuan membayar (ATP, ability to pay) dari penggunanya.

Tabel 1 Komponen biaya penentuan tarif angkutan kereta api

\begin{tabular}{|c|c|}
\hline $\begin{array}{l}\text { SARANA KA } \\
-\quad \text { Lokomotif } \\
-\end{array}$ & $\begin{array}{l}\text { PRASARANA KA } \\
\text { - Jalur KA (rel, terowongan, jembatan) } \\
\text { - Stasiun } \\
\text { - fasilitas operasi (sinyal, telekomunikasi dan LAA(sintelis) }\end{array}$ \\
\hline $\begin{array}{l}\text { A. MODAL } \\
\text { 1.Penyusutan aset tetap } \\
\text { 2. Bunga modal (via bank) } \\
\text { 3. Bunga modal } \\
\text { B. BIAYA OPERASI } \\
\text { 1.Biaya Langsung Tetap } \\
\text { a. Biaya pegawai awak sarana } \\
\text { b. Asuransi } \\
\text { 2.Biaya Lansung Tidak Tetap } \\
\text { a. BBM } \\
\text { b. LAA (listrik arus atas) } \\
\text { c. Air bersih (untuk penumpang) } \\
\text { d. OTC (petugas kebersihan) } \\
\text { e. Cucian sarana harian, bulanan, salonisasi } \\
\text { f. Pelumas lokomotif/KRD } \\
\text { g. Pelumas genset } \\
\text { h. Tunjangan kerja operasional awak sarana } \\
\text { 3.Biaya Tidak Langsung Tetap } \\
\text { a. Biaya pegawai non awak(gaji+tunjangan) } \\
\text { b. Tunjangan kerja operasional (non awak/th) } \\
\text { C.BIAYA PERAWATAN SARANA }\end{array}$ & $\begin{array}{l}\text { A. Biaya penggunaan Prasarana } \\
\text { - Jalur KA (rel, terowongan, jembatan) } \\
\text { - Stasiun } \\
\text { - fasilitas operasi (sinyal, telekomunikasi dan } \\
\text { LAA(sintelis) } \\
\text { a) Prasarana milik PT.KAI } \\
\text { 1. Penyusutan bangunan } \\
\text { 2. Pemeliharaan Bangunan } \\
\text { 3. Administrasi kantor } \\
\text { 4. Listrik, Air dan Telepon } \\
\text { b) Biaya Umum Kantor } \\
\text { c) Pajak perusahaan } \\
\text { d) Perizinan dan sertifikasi } \\
\text { B. Biaya Tidak Langsung Tidak Tetap } \\
\text { a. Biaya Pemasaran (promosi, agen dan dokumen) } \\
\text { b. Penelitian dan pengembangan (litbang) } \\
\text { c. Pengembangan SDM (diklat pegawai) } \\
\text { C.BIAYA PERAWATAN PRASARANA }\end{array}$ \\
\hline
\end{tabular}

\subsection{Variabel Biaya}

Silaen (1991) melakukan penelitian Analisis Biaya Kereta Api Barang Untuk Kebijakan Tarif Dengan Menggunakan Konsep Full-Costing untuk Rute Bandung-Jakarta. variabel biaya yang diteliti yaitu : Loko, gerbong, crew, dan jam operasi serta fixed cost berupa: biaya terminal, balai yasa dan dipo. Sedang Kusdyanto (1994) meneliti tentang Tarif Kereta Api Penumpang Komersil (Studi Kasus Kereta Api Parahyangan Jakarta-Bandung Pp). Variabel yang diteliti tentang Tarif berdasarkan waktu/jadwal pemberangkatan. Widianto (2005) membuat Laporan Advis Teknis berupa Perhitungan Penyesuaian Tarif Tol Akibat Overloading. dengan penekanan penelitian pada Tarif tol sebagai fungsi biaya kompensasi kerusakan jalan dan biaya nilai tambahan lainnya atau kompensasi manfaat. Penelitian tersebut mengkombinasikan konsep finasial dengan ekonomi secara langsung. Wibowo (2006) melakukan peneliataan tentang Penentuan Indeks Tarif Jalan Tol Akibat Pengaruh Beban Sumbu Kendaraan (Studi Kasus: Jalan Tol Jakarta-Cikampek, Ruas Cibitung-Cikampek). Variabel yang diteliti yaitu Indeks tarif, ESAL, CESAL, Umur Rencana Perkerasan Jalan. Indeks Tarif Sebagai Analogi Tarif Berdasarkan Rasio ESAL Kendaraan Terhadap ESAL Standar (Rasio Tarif dianggap sama dengan Rasio ESAL (Hubungan Langsung). Adeltua (2007) melakukan penelitian tentang Pemodelan Tarif Jalan Tol Berdasarkan Simulasi Kontribusi Faktor Perusakan Jalan (Studi Kasus Jalan Tol Tangerang-Merak). Variabel yang diteliti yaitu ESA, CESA, Umur Rencana Perkerasan Jalan, Biaya Pemeliharaan Jalan Berdasarkan Golongan Kendaraan, Koefisien Kontribusi, Tarif Dasar, Tarif Overloading, Hubungan Tarif dengan Kontribusi Faktor Perusakan (ESA) dilihat Dalam Konteks Mekanisme Cashflow Kelayakan Investasi (hubungan tarif dengan kontribusi ESA bersifat tidak langsung). Tarif tol sebagai fungsi satuan biaya pengembalian investasi dan satuan peningkatan biaya investasi sebagai 
akibat dampak overloading.

\section{METODOLOGI}

Metode survei company interview dilakukan dengan mendatangi perusahaan-perusahaan untuk mencari data. Pengambilan data dilapangan menggunakan tahapan-tahapan, yaitu: studi pendahuluan, desain kuisioner, survai pendahuluan, desain sampel, survai menyeluruh, kompilasi data dan analisis data. Alur langkah penelitian dapat dilihat pada Gambar 1.

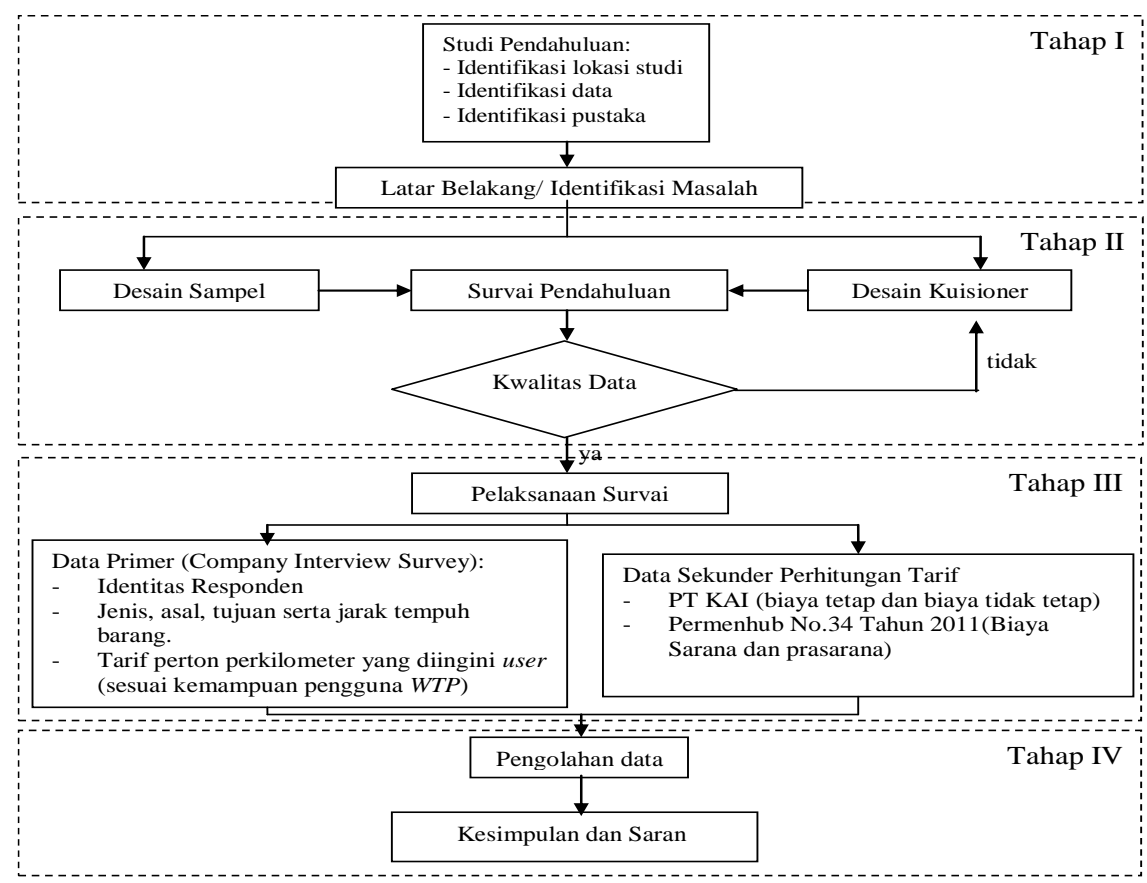

Gambar 1 Diagram Alur Langkah Penelitian

Dalam menentukan tarif angkutan barang moda kereta api jalur Padang-Solok menggunakan pendekatan biaya operasional kereta api (BOKA) yang terlihat dalam perhitungan tarif menurut Peraturan Menteri Perhubungan no. 34 tahun 2011 serta perhitungan tarif menurut perhitungan PT Kereta Api Indonesia Divisi Regional II Provinsi Sumatera Barat ditambah dengan persentase keuntungan yang diperkenangkan, untuk perhitungan tarif dasar dapat dilihat pada Rumus. 1

$$
\text { Rumus Tarif Dasar }=\frac{((100 \%+\text { Keuntungan }) \times \text { Biaya Pokok })}{(\text { LF } x \text { kapasitas } x \text { jarak tempuh })}=R p / K m
$$

\subsection{Data Primer}

Survei data primer ini dilakukan untuk mendapatkan data-data yang langsung dicari dan dikumpulkan oleh surveyor. Teknik pengumpulan data diperoleh melalui pengisian kuisioner dan wawancara langsung dengan pimpinan perusahaan atau staf yang menangani bidang distribusi dan transportasi angkutan barang moda darat yang melewati jalur Padang - Solok atau sebaliknya .

\subsection{Data Sekunder}

Data sekunder dari penelitian ini diperoleh dari instansi pemerintah dan badan usaha di Kota Padang yaitu Dinas Perhubungan Komonikasi dan Informatika UPTD Penimbangan Kendaraan Bermotor untuk mendapatkan data angkutan barang yang mendominasi angkutan barang PadangSolok. PT KAI Divre II Sumatera Barat untuk mendatkan data perhitungan tarif angkutan barang 
kereta api serta biaya operasional kereta api serta data data lain yang diperlukan.Instansi lain seperti Badan Pusat Statistik kota Padang serta Dinas Perindustrian dan Perdagangan.

\section{HASIL DAN PEMBAHASAN}

\subsection{Hasil Pengolahan Data Survei}

Jenis komoditi yang melewati jalur moda darat Padang-Solok ataupun sebaliknya di dominasi oleh angkutan semen, batu bara, sawit, CPO, kelontong, pupuk. Dari Gambar 2 menunjukkan porsentase jenis angkutan barang, dimana proporsi responden pengguna angkutan semen sebanyak $30 \%$, angkutan batu bara sebanyak 16\%. Beras sebesar 19\%, karet sebesar 19\%, bijih besi sebesar 7\% kelontong sebesar 7\%, CPO se besar 7\% serta inti sawit sebesar 5\%.

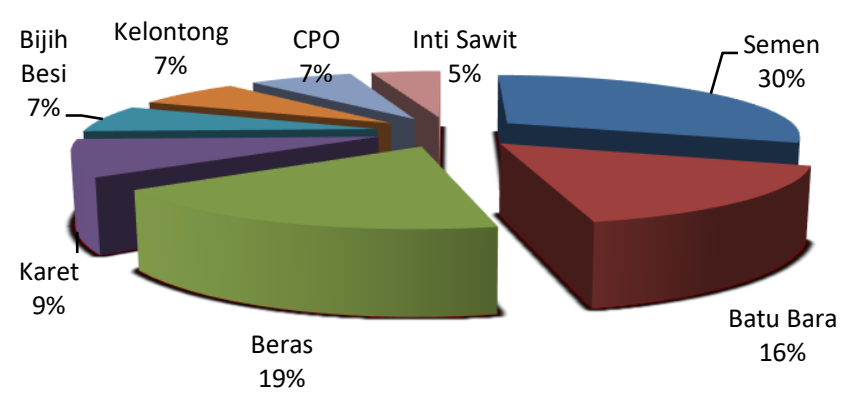

Gambar 2 Grafik Jenis Komoditi Angkutan Barang

Dari Gambar 3 dapat dilihat tanggapan para responden terhadap tarif angkutan barang yang diinginkan dimana $28 \%$ tarif yang diinginkan antara tujuh ratus lima puluh rupiah sampai seribu rupiah. $21 \%$ responden memilih tarif yang diinginkan antara dua ratus limapuluh rupiah sampai limaratus rupiah, serta kecil dari dua ratus limapuluh rupiah. $14 \%$ tarif yang diinginkan antara limaratus sampai tujuh ratus limapuluh rupiah, sebanyak $7 \%$ responden memilih tarif besar dari seribu limaratus rupiah. 9\% memilih tarif dariseribu rupiah sampai seribu duaratus lima puluh rupiah. sisanya sebesar $2 \%$ memilih tarif seribu dua ratus lima puluh sampai seribu limaratus rupiah (satuan ton $/ \mathrm{km}$ ).

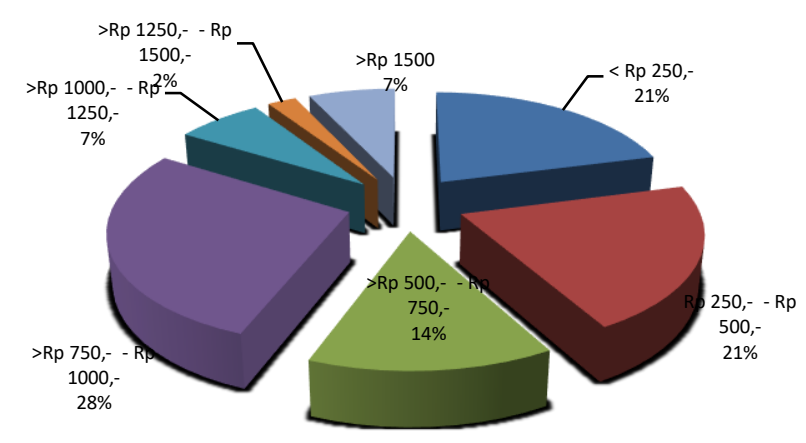

Gambar 3 Grafik Tarif barang KA yang diinginkan perton perkilometer saat ini

\subsection{Perhitungan tarif barang versi PT KAI}

Perhitungan tarif yang dilakukan menurut versi PT Kereta Api Indonesia terdiri dari biaya tidak tetap seperti dilihat pada tabel.3 dan biaya tetap terlihat pada Tabel. 4, dimana variabel dari biaya tidak tetap berupa biaya BBM, biaya pelumas, biaya perawatan lokomotif, perawatan gerbong, 
biaya penyusutan lokomotif,dan perawatan jalan. Biaya tetap berupa premi awak kereta api, premi stasiun dan premi lintasan.

Tabel.3 Rekapitulasi Biaya Tidak Tetap

\begin{tabular}{|ll|l|}
\hline Komponen Biaya Tidak Tetap & Rp/Lintas \\
\hline a) Biaya BBM & 1.673 .438 \\
b) Biaya Pelumas & 318.750 \\
c) Perawatan Lokomotif & 318.750 \\
d) Perawatan Gerbong & 395.117 \\
e) Penyusutan Lokomotif & 318.750 \\
f) Awak Kereta Api & 375.000 \\
g) Stasiun & 60.000 \\
\hline Jumlah biaya tidak tetap & $\mathbf{3 . 4 5 9 . 8 0 5}$ \\
\hline
\end{tabular}

Tabel.4 Rekapitulasi Biaya Tetap

\begin{tabular}{|ll|l|}
\hline Komponen Biaya Tetap & Rp/Lintas \\
\hline a) & Pegawai Operasi & 72.756 \\
b) & Perawatan Jembatan & 25.270 \\
c) & Perawatan Sinyal & 32.732 \\
d) & Karyawan Perawatan Sarana & 50.844 \\
e) & Karyawan Perawatan & 74.389 \\
& Prasarana & 15.024 \\
f) $\quad$ Biaya Umum Dipo & 5.825 \\
g) Biaya Umum Instalasi tetap & 124.020 \\
h) Biaya Umum Lainnya & 105.000 \\
i) $\quad$ Biaya Umum Kantor Pusat & $\mathbf{5 0 5 . 8 8 7}$ \\
\hline Jumlah biaya tetap &
\end{tabular}

Jumlah Biaya

$$
\begin{array}{ll}
\text { Biaya Tidak Tetap } & =R p 3.459 .805,- \\
\text { Biaya Tetap } & =\operatorname{Rp~505.887,-} \\
& =\operatorname{Rp~3.965.692,-}
\end{array}
$$

Tarif $1 \mathrm{KKW}=\mathrm{Rp} 3.965 .692+\mathrm{Rp} 505.887: 4 \mathrm{KKW}=\mathrm{Rp} 1.052 .136,-$

Tarif angkutan/ton $=\operatorname{Rp} 1.052 .136,-: 25$ ton $\quad=\operatorname{Rp~42.085,-}$

Nilai tarif yang didapatkan perton perkilometer adalah:

Ton $\mathrm{km}$

$$
=\frac{\operatorname{Rp~42.085,-}}{53.13 \mathrm{~km}} \quad=\operatorname{Rp} 792,19
$$

Tarif termasuk margin $10 \%$

$$
=\operatorname{Rp} 871,42 / \mathrm{ton} / \mathrm{km} \text {. }
$$

\subsection{Perhitungan tarif barang menurut Peraturan Menteri Perhubungan no.34 tahun 2011.}

\begin{tabular}{|c|c|}
\hline Komponen Biaya Modal & Rp/Lintas \\
\hline $\begin{array}{l}\text { a) Penyusutan Aset Tetap sarana } \\
\text { Perkeretaapian } \\
\text { b) Bunga Modal }\end{array}$ & 5.166 .976 \\
\hline Jumlah Biaya Modal & 7.833 .803 \\
\hline
\end{tabular}

Perhitungan tarif barang versi Peraturan menteri perhubungan terdiri dari biaya modal dengan rekapitulasi perhitungan dapat dilihat pada Tabel.5, biaya operasi pada Tabel.6, Biaya perawatan pada Tabel.7.

Tabel.5 Rekapitulasi Biaya Modal 
Tabel.6 Rekapitulasi Biaya Operasi

\begin{tabular}{|c|c|}
\hline Komponen Biaya Operasi & Rp/Lintas \\
\hline \multicolumn{2}{|l|}{ Biaya Langsung Tetap } \\
\hline - Biaya Pegawai Awak Sarana & 55.715 \\
\hline \multicolumn{2}{|l|}{ Biaya Langsung Tidak Tetap } \\
\hline - $\quad$ BBM Lokomotif & 516.522 \\
\hline BBM Genset & 7.844 \\
\hline Cucian sarana harian, bulanan dan salonisasi & 150.000 \\
\hline Pelumas Lokomotif & 581.708 \\
\hline Pelumas Genset & 79.360 \\
\hline - $\quad$ Tunjangan Kerja Operasional (TKO) Awak Sarana & 1.873 .825 \\
\hline \multicolumn{2}{|l|}{ Biaya Tidak Langsung Tetap } \\
\hline - $\quad$ Biaya Pegawai Non Awak KA (Gaji dan tunjangan) & 24.671 \\
\hline Tunjangan Kerja Operasional & 19.736 \\
\hline \multicolumn{2}{|l|}{ Prasarana } \\
\hline - Penyusutan Bangunan & 12.335 \\
\hline - Pemeliharaan Kantor & 8.223 \\
\hline - Administrasi Kantor (ATK, SPJ, Percetakan) & 1.027 \\
\hline - Listrik, air dan telepon & 3.700 \\
\hline Biaya Umum Kantor & 5.345 \\
\hline Pajak Perusahaan & 12.335 \\
\hline - $\quad$ Perizinan dan Sertifikasi & 2.005 \\
\hline \multicolumn{2}{|l|}{ Biaya Tidak Langsung Tidak Tetap } \\
\hline - $\quad$ Biaya Pemasaran (Promosi, agen, dan dokumen) & 6.578 \\
\hline Penelitian dan Pengembangan (Litbang) & 3.083 \\
\hline - $\quad$ Pengembangan SDM (Pendidikan dan latihan Pegawai & 8.223 \\
\hline Jumlah biaya Operasi & 3.372.293 \\
\hline
\end{tabular}

Tabel.7 Rekapitulasi Biaya Perawatan

\begin{tabular}{|c|c|}
\hline Komponen Biaya Perawatan & Rp/Lintas \\
\hline \multicolumn{2}{|l|}{ Biaya Perawatan sarana } \\
\hline - $\quad$ Perawatan Kereta & 782.318 \\
\hline Perawatan Lokomotif & 1.323 .298 \\
\hline $\begin{array}{l}\text { - Semi Pemeriksaan Akhir(SPA) dan Pemeriksaan Akhir } \\
\text { (PA) }\end{array}$ & \\
\hline - Perbaikan Kereta & 543.335 \\
\hline - $\quad$ Perbaikan Lokomotif & 650.802 \\
\hline \multicolumn{2}{|l|}{ Biaya Suku Cadang } \\
\hline - $\quad$ Suku cadang diluar perawatan dan perbaikan sarana) & 375.000 \\
\hline Jumlah biaya Perawatan & 3.673.755 \\
\hline
\end{tabular}

Estimasi perhitungan tarif

- $\quad$ Biaya Pokok $=\sum$ biaya modal $+\sum$ biaya operasi $+\sum$ biaya perawatan $\quad=R p$ 17.116.985,-/lintas

- Keuntungan dihitung $10 \%$ dari biaya pokok $\quad=$ Rp 1.711.698,-/lintas

Faktor muat $=500$ ton/rangkaian

Kapasitas $\quad=600$

Jarak tempuh $=36,36 \mathrm{~km}$

- Tarif dasar $=\frac{((100 \%+\text { Keuntungan }) \times \text { Biaya Pokok })}{(\text { LF } x \text { kapasitas } x \text { jarak tempuh })} \quad=\mathrm{Rp} 2.664 .769,-/$ lintas

- $\quad$ Tarif jarak =Tarif Dasar $x$ Jarak Tempuh

Estimasi yang digunakan

$\begin{array}{ll}\text { - } \quad \text { Tarif dasar } & =\mathrm{Rp} 2.664 .769,-/ \text { lintas } \\ \text { - Jarak tempuh } & =36,65 \mathrm{~km}\end{array}$

Tarif jarak

$=\operatorname{Rp} 97.663 .783,-$ /lintas

- Tarif jarak batas bawah = biaya pokok $x$ keuntungan

Estimasi yang digunakan
- Biaya Pokok
$=\operatorname{Rp} 17.116 .985,-/$ lintas
- Keuntungan dihitung $10 \%$ dari biaya pokok
$=\mathrm{Rp} 1.711 .698,-$-lintas 
Tarif jarak batas bawah

$=\operatorname{Rp} 18.828 .684,-/$ lintas

- Tarif per ton per kilometer

Estimasi yang digunakan

- Tarif jarak batas bawah

- Jumlah gerbong

- Kapasitas angkut

$=\operatorname{Rp~18.828.684,-/lintas}$

$=20$ rangkaian

$=30$ ton/gerbong

Rumus yang digunakan $=\frac{\text { tarif jarak batas bawah }}{\text { jumlah gerbong } x \text { kapasitas angkut } x \text { jarak tempuh }}$

Tarif perton perkilometer

$=\operatorname{Rp} 856,24 /$ ton $/ \mathrm{km}$

\subsection{Perhitungan Tarif berbagai jenis Angkutan barang KA menurut perhitungan PT KAI.}

Nilai tarif dari hasil perhitungan berbagai jenis komoditi angkutan barang kereta api menurut perhitungan PT Kereta Api Indonesia Divisi Regional II Provinsi Sumatera Barat dapat dilihat pada Tabel.8

Tabel.8 Hasil perhitungan tarif berbagai komoditi angkutan barang

\begin{tabular}{clc}
\hline NO & KOMODITI & $\begin{array}{c}\text { Tarif Angkutan Ton/Km } \\
(\mathbf{R p})\end{array}$ \\
\hline 1 & Semen & 871.42 \\
\hline 2 & Batu Bara & 709.11 \\
3 & CPO & 709.11 \\
\hline 4 & Karet & 704.18 \\
5 & Beras & 699.24 \\
\hline 6 & Pupuk & 871.42 \\
7 & Inti sawit & 709.11 \\
\hline 8 & Kelontong & 704.18 \\
\hline
\end{tabular}

Sumber: Hasil Perhitungan

Dari hasil perhitungan didapatkan nilai tarif berbagai komoditi angkutan barang mulai dari yang terendah $\mathrm{Rp}$ 699,24 perton perkilometer pada tarif angkutan komoditi beras. Diikuti dengan komoditi karet dan kelontong sebesar Rp 704.18,- perton perkilometer, CPO, batu bara dan inti sawit sebesar Rp 709.11,-, semen dan pupuk sebesar Rp 871,42 perton perkilometer.

\subsection{Pembahasan}

Dari hasil survei yang dilakukan diperoleh nilai ATP (Abillity to Pay) rata-rata pengguna jasa angkutan barang untuk batu bara sebesar Rp 530,85,- perton perkilometer, semen sebesar Rp 1.005,44,- /ton /km, CPO sebesar Rp 519.78,- /ton /km, karet sebesar Rp 552.47,- /ton /km, beras sebesar Rp 1.027,73,- /ton /km, pupuk sebesar Rp 445,45,- /ton /km, inti sawit sebesar Rp 500.00,/ton /km, kelontong sebesar Rp 670.53,- /ton /km.

Nilai Willingness to Pay rata-rata pengguna jasa angkutan barang untuk batu bara sebesar Rp 499.97,- perton perkilometer, semen sebesar Rp 823.91,-- /ton /km, CPO sebesar Rp 430.00,- /ton $/ \mathrm{km}$, karet sebesar Rp 471.94,- /ton / km, beras sebesar Rp 855.06,- /ton /km, pupuk sebesar Rp 550.00 ,- /ton /km, inti sawit sebesar Rp 166.67,- /ton /km, kelontong sebesar Rp 633.83,- /ton / km, Hasil ini didapatkan dari pengumpulan kuisioner sebanyak 43 sampel. Sasaran kuisioner adalah mobil angkutan barang yang melewati moda jalan darat dari Padang ke Solok dan sebaliknya.

\section{8 | JURNAL REKAYASA SIPIL}


Hasil yang didapatkan dari empat metode perhitungan tarif yang dilakukan menunjukkan nilai yang berfariasi. Dari survei yang dilakukan didapatkan pebedaan nilai yang beragam sedangkan hasil perhitungan versi PT KAI serta perhitungan Permenhub selisih perbedaannya tidak begitu signifikan. Seperti dapat dilihat pada Gambar 4.

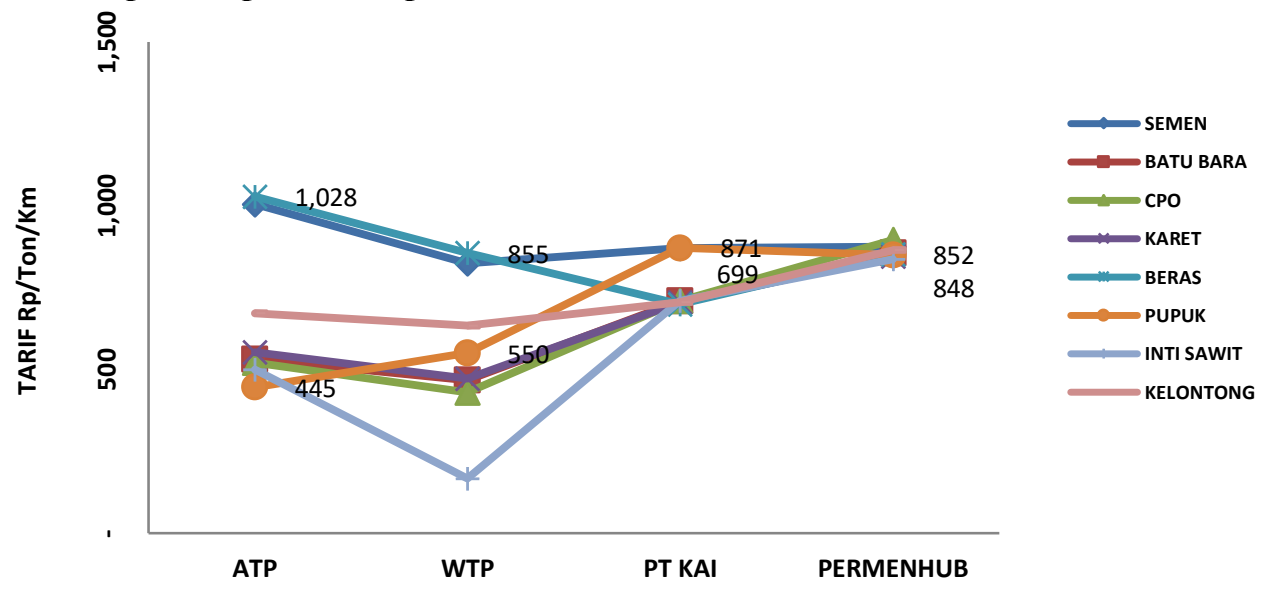

Gambar 4 Perbandingan Nilai Tarif

Kesimpulan hasil analisis tarif angkutan barang kereta api jalur Padang-Solok dapat dilihat pada Gambar 5 dan Gambar 6, sebagai berikut :

- $\quad$ Kondisi WTP dibawah KAI, PERMENHUB dan ATP

Terdapat pilihan untuk memperbaiki tingkat pelayanan hingga WTP-nya naik sampai Rp 876,atau menurunkan tarif (tanpa perbaikan tingkat pelayanan) sampai Rp 824,- (sesuai Gambar.5) selanjutnya kelebihan Rp 52,- harus disubsidi. Seperti terlihat pada angkutan komoditi semen.

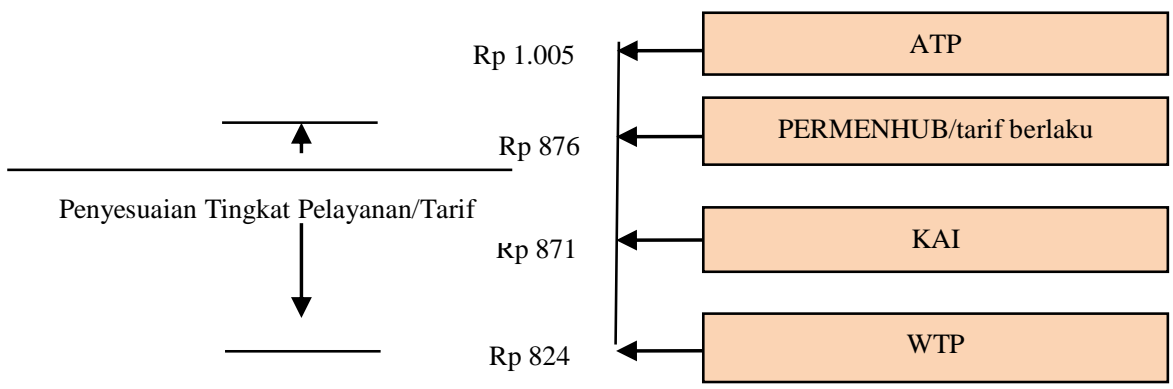

Gambar 5 Tarif diatas WTP Namun Dibawah ATP

- Kondisi WTP dibawah KAI, PERMENHUB dan ATP

Dalam hal ini subsidi ditanggungkan pihak regulator sebesar Rp 389,- karena tarif minimal didapat sebesar Rp 856,- yang merupakan tarif berdasarkan operasional sebagai cosh dan benefit (sesuai Gambar 6) Seperti terlihat pada angkutan komoditi batu bara. Kasus yang sama terlihat pada angkutan komoditi CPO, karet, inti sawit, kelontong dan pupuk.
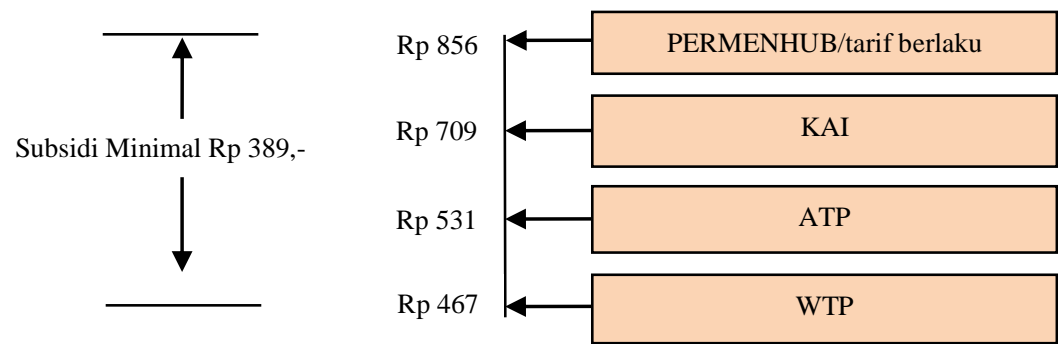

Gambar 6 Tarif diatas WTP dan ATP

VOLUME xx NO. xx, JANUARI 2014 | 9 


\section{KESIMPULAN}

Berdasarkan perhitungan yang telah dilakukan pada penelitian ini (dengan jumlah sampel pengguna angkutan barang moda darat untuk jalur Padang - Solok sebanyak 43 responden diperoleh kesimpulan sebagai berikut :

- Karakteristik dari pengguna angkutan barang Padang-Solok paling banyak adalah angkutan semen. Jenis angkutan yang banyak digunakan adalah truk 3 as dengan kapasitas angkut barang diatas 20 ton. Tarif angkutan barang yang dikenakan saat ini sudah sesuai. Perhitungan pembayaran yang banyak dilakukan berdasarkan tarif perton per tempat tujuan.

- Dari hasil survei diperoleh nilai ATP (Abillity to Pay) rata-rata pengguna jasa angkutan barang untuk batu bara sebesar Rp 530,85, semen sebesar Rp 1.005,44, CPO sebesar Rp 519.78, karet sebesar Rp 552.47, beras sebesar Rp 1.027,73, pupuk sebesar Rp 445,45, inti sawit sebesar Rp 500.00, kelontong sebesar Rp 670.53,- /ton $/ \mathrm{km}$.

- Nilai WTP (Willingness to Pay) rata-rata pengguna jasa angkutan barang untuk batu bara sebesar Rp 499.97,-- perton perkilometer, semen sebesar Rp 823.91,- /ton /km, CPO sebesar Rp 430.00,- /ton $/ \mathrm{km}$, karet sebesar Rp 471.94,- /ton /km, beras sebesar Rp 855.06,- /ton $/ \mathrm{km}$, pupuk sebesar Rp 550.00,- /ton / /km, inti sawit sebesar Rp 166.67,- /ton /km, kelontong sebesar Rp 633.83,- /ton / km, Hasil ini didapatkan dari pengumpulan kuisioner sebanyak 43 sampel. Sasaran kuisioner adalah mobil angkutan barang yang melewati moda jalan darat dari Padang ke Solok dan sebaliknya.

- Besar nilai tarif berdasarkan metode perhitungan PT Kereta Api Indonesia Devisi Regional II Sumatera Barat adalah :

- Untuk angkutan semen dan pupuk sebesar Rp 871,42,-/ton/km.

- Angkutan batu bara sebesar Rp 938,96,-/ton/km,

- Angkutan batu bara, CPO dan inti sawit sebesar Rp 709,00,-/ton/km,

- Angkutan karet dan kelontong sebesar Rp 704,18,-/ton/km,

- Angkutan beras sebesar Rp 699,24,-/ton/km,

Perbedaan besaran tarif masing-masing komoditi didapat dari jumlah formasi rangkaian gerbong barang kereta api serta asal dan tujuan barang komoditi yang diangkut.

- Tarif berdasarkan Peraturan Menteri Perhubungan no. 34 tahun 2011 untuk batu bara sebesar Rp 856,24,-/ton/km, semen sebesar Rp 875,83,-/ton/km, untuk CPO sebesar Rp 895,43,/ton/km, karet sebesar Rp 844,48,-/ton/km, beras sebesar Rp 852,32,-/ton/km, pupuk sebesar Rp 848,40,-/ton/km, inti sawit sebesar Rp 836,65,-/ton/km, serta kelontong sebesar Rp 864,08,/ton/km, perhitungan ini didapat dari penjumlahan biaya-biaya modal, biaya operasi, biaya langsung, biaya tidak langsung serta biaya perawatan sarana dan prasarana.

- Terdapat dua kondisi tarif angkutan barang kereta api jalur padang solok yaitu ; a. Kondisi WTP dibawah KAI, PERMENHUB dan ATP dimana terdapat pilihan untuk memperbaiki tingkat pelayanan hingga WTP-nya naik sampai Rp 876,- atau menurunkan tarif (tanpa perbaikan tingkat pelayanan) sampai Rp 824,- selanjutnya kelebihan Rp 52,- harus disubsidi. Seperti terlihat pada angkutan komoditi semen. b.Kondisi WTP dibawah KAI, PERMENHUB dan ATP dalam hal ini subsidi ditanggungkan pihak regulator sebesar Rp 389,- karena tarif minimal didapat sebesar Rp 856,- yang merupakan tarif berdasarkan operasional sebagai cosh dan benefit. Seperti terlihat pada angkutan komoditi batu bara. Kasus yang sama terlihat pada angkutan komoditi CPO, karet, inti sawit, kelontong dan pupuk.

- Dengan melihat hasil ATP (Abillity to Pay) dan WTP (Willingness to Pay), tarif berdasarkan perhitungan biaya operasional kendaraaan dan perhitungan PT Kereta Api Indonesia. Divre II Sumatera Barat serta perhitungan berdasarkan peraturan mentreri perhubungan tentang perhitungan tarif barang kereta api dalam hal ini pemerintah dapat mempertimbangkan pembangunan jalur kereta api Padang - Solok. 


\section{DAFTAR PUSTAKA}

Adeltua, HP (2007). Pemodelan Tarif Jalan Tol Berdasarkan Simulasi Kontribusi Faktor Perusakan Jalan (Studi Kasus Jalan Tol Tangerang-Merak).Tesis Program Magister TR. ITB.

Badan Perencanaan Pembangunan Daerah Provinsi Sumatera Barat (2011). 'Bahan Focus Group Discussion (FGD) Review Master Plan Jalur Kereta Api Pulau Sumatera'

Corder, (2008). Pengertian Biaya - Biaya Perawatan, http://thesis.binus.ac.id/asli/bab2/2008-1-00448-TISI-bab\%202.pdf (diakses 10 desember 2013)

Departemen Perhubungan Ditjen Perkeretaapian (2010). Buku -8A Laporan Akhir (Final Report). PT. Jasakons Putra Utama.

Dinas Perhubungan Komunikasi dan Informatika UPTD Penimbangan Kendaraan Bermotor (2011). Laporan Tahunan Tahun 2011. Padang.

Divre II Sumatera (2011). Bahan Paparan KA Divre II Sumatera Barat. Sumatera Barat: Divre II Sumatera Barat

Fitriyanto, B (1998). Analisis Tarif Tol Berdasarkan Willingness to Pay dan Ability to Pay, Tesis Magister, ITB, Bandung.

Kusdiyanto (1994). Evaluasi Tarif Kereta Api Penumpang Komersil (Studi Kasus Kereta Api Parahyangan Jakarta-Bandung Pp).Tesis Program Magister TR. ITB.

Menteri Hukum dan HAM (2007). Undang-Undang Nomor 23 Tahun 2007 tentang Perkeretaapian, Jakarta.

Kementerian Perhubungan (2011). PM. 34 Tahun 2011 Tatacara Perhitungan dan Penetatan Tarif Angkutan Orang dan Barang Dengan Kereta Api, Jakarta.

Natsir, M. 2011, 'Kebijakan Investasi Infrastruktur PU', dokumen disampaikan pada Pelatihan Investasi Infrastruktur, Jakarta, 3-5 Oktober.

Prayitno, I (2011). Focus Group Discussion, Reviw Master Plan Jalur Kereta Api Pulau Sumatera, kata sambutan gubernur Sumatera Barat, Padang, 6 Juli 2011.

Pemerintah Republik Indonesia (1998). Peraturan Pemerintah Republik Indonesia Nomor 69 Tahun 1998 Tentang Prasarana dan Sarana Kereta Api.

PT. Diksa Intertama (2011). Review Masterplan Jalur KA Pulau Sumatera, Focus Group Discussion (FGD) 6 Juli 2011 di Padang.

PT. Jasakons Putra Utama (2010). Buku -8A Laporan Akhir (Final Report), Bandung.

Rajasa, M,H (2010). 'Panduan Bagi Investor Dalam Investasi Di Bidang Infrastruktur, kata pengantar Kerjasama Pemerintah Dan Swasta (KPS), Kementerian Koordinator Bidang Perekonomian.Jakarta

Seffrus, T (2012). 'Estimasi Angkutan Barang Shortcut Padang-Solok Dari Peralihan Moda Truk Ke Kereta Api Sebagai Pertimbangan Pembangunan Proyek Kerjasama Pemerintah-Swasta'. Padang: Tesis, Pasca Sarjana Universitas Andalas.

Silaen, S (1991). Analisis Biaya Kereta Api Barang Untuk Kebijakan Tarif Dengan Menggunakan Konsep Full-Costing (Rute Bandung-Jakarta). Tesis Program Magister TR. ITB.

Trans Media (2010). Majalah Kementerian Perhubungan Republik Indonesia Edisi 1, Jakarta

Warpani, S (2002). Pengelolaan Lalu Lintas Dan Angkutan Jalan. Bandung. Penerbit : ITB.

Yusticia,P (2010). Studi Tarif Angkutan Umum Masal Kota Padang. Padang: Tugas akhir, Fakultas Teknik Universitas Andalas. 